Dept. of Anatomy and Histology,

Fac. Vet. Med., Assiut University, Head of Dept. Prof. Dr. A. Hifny.

\title{
MORPHOLOGICAL STUDIES ON THE GUTTURAL POUCH OF DONKEY \\ 1 - THE LINING EPITHELIUM \\ (With 9 Fig.)
}

By

\section{YOUSRIA A. ABDEL-RAHMAN; A.O. SALEM and A. ABOU-ELMAGD}

(Received at 28/9/1994)

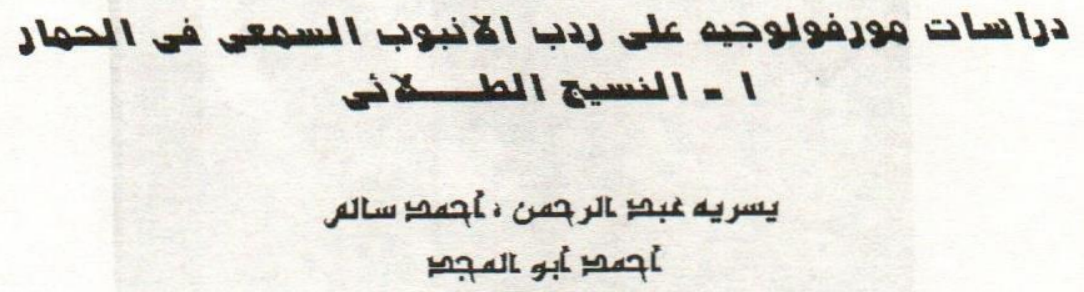

اجرى هذا البحث باستخدام المجهر الاكترونى بغرف دراسة التركيب الدقيق لطلائية ردب

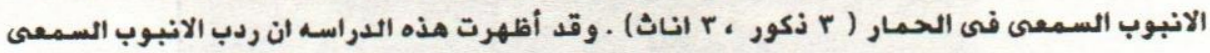
مبطن بنسيج طلائى عمادى مهدب من النوع عديد الطبقات الكاذب ويتكون من أربعة أنواع من الخلايا

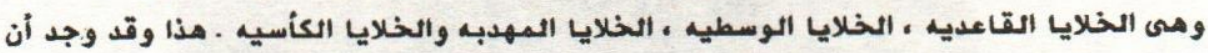
الخلايا القاعديه ذات عتامه الكترونيه وتحتوى على عديد من الخيوط المؤثره ـ الخلايا الوسطيه

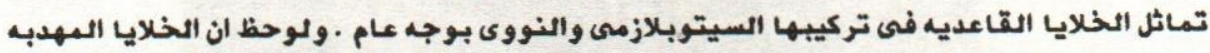
تنقسم الى خلايا فاتحه واخرى معتمه وكانت الخلايا المعتمه أكثر وفره فى الطبقه الطلائيه .

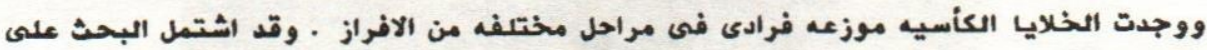

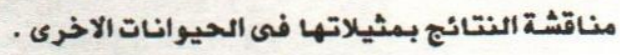




\section{SUMMARY}

The epithelium of the guttural pouch of the donkey has been studied at the ultrastructural level. It was found to be a typical pseudostratified ciliated columnar epithelium formed of basal, intermediate, clliated and goblet cells. The basal cells possessed numerous tonofilaments and a greater electron density than that of other cells. The intermediate cells had less tonofilaments than that of the basal cells, otherwise they were structurally similar in both cytoplasmic and nuclear component. The ciliated cells in the donkey guttural pouch epithelium were divided into light and dark one. The latter were the most abundant cell type in the epithelial layer. While the goblet cells were scattered singly along the length of the epithelium. These mucous producing goblet cells were observed at various stages of secretion. Lymphocytes and mast cells were observed also within the guttural pouch epithelium.

Keywords: Epithelium, guttural pouch, donkey.

\section{INTRODUCTION}

Several anatomical, histological and surgical studies (COOK, 1973; SISSON, 1975; SCHUMMER and NICKEL, 1979; FREEMAN, $1980 \mathrm{a}, \mathrm{b} ;$ KOENIG, 1984; DELLMAN and BROWN, 1987; LIEBICH, 1990 $B A N K S, 1993$ ) dealing with the guttural pouches in equidae have been reported.

The guttural pouches (Diverticulum tubae auditivae) are paired diverticula of the Eustachian tubes extending from the nasopharynx to the middle ear. From the medical point of view this structure suffer from empyema, tympany and mycosis (MILNE and FESSLER, 1972; HAYNES, 1984 and MISK et al., 1992) which are the most common affections being recorded. Although the available literatures contain no information about its fine structure. Concequently the present investigation aims to study the normal structure of the guttural pouch in the donkey using transmission electron microscopy.

\section{MATERIAL and METHODS}

The guttural pouches from 3 male and 3 female donkeys were used in this study. This tissue was cut into small pieces and fixed by immersion in $2.5 \%$ glutaraldehyde with $2.5 \%$ paraformaldehyde in $0.1 \mathrm{M} \mathrm{Na}$ - cacodylat buffer $(\mathrm{pH} 7.3)$ for 2

Assiut Vet. Med. J. Vol. 32 No. 63, October 1994. 
hours. The tissue was washed in the same buffer, postfixed in buffered $1 \%$ osmium tetroxide, dehydrated in ascending concentrations of alcohol and embedded in Epon- Araldite. Semithin sections were cut on an LKB microtome and stained with toluidine blue and alcian blue-PAS (BOECK, 1984) for light microscopical examination. Ultrathin sections were doubly stained with uranyl acetate and lead citrate, examined and photographed with JEOL 100 CXII electron microscope.

\section{RESULTS}

In semithin section (Fig. 1), the general character and histological arrangement of cellular constituents of the guttural pouch epithelium of the doneky was a typical pseudostratified ciliated columnar epithelium with goblet cells. The epithelium showed numerous irregular invaginations of variable depth. Some goblet cells open in these invaginations and many intraepithelial mast cells with blue stained cytoplasm were observed.

At the ultrastructural level, four cell types were distinguished: Basal, intermediate, ciliated columnar and goblet. All the cells rest on the basal lamina and all except the basal and intermediate cells extend to the surface (Fig. 3)

Basal cells:

The basal cells (Fig. 2) were elongated and or irregularly oval. Their lateral surfaces make contact with neighbouring basal cells as well as the other adjacent columnar cells by cytoplasmic interdigitations and sparse, poorly developed desmosomes. These cells were seen rest on a thin irregular basal lamina which was intimately applied to the inferior aspect of them and joined together with hemidesmosomes at a variable distance. The intercellular spaces varied in width; the cells may be tightly apposed to their neighbours with little intervening space or the intercellular space may be substantial and contained numerous cytoplasmic extensions from adjacent cells.

The oval or irregular rounded nuclei occupied the major portion of the cells. They showed numerous irregular deep indentations and segmentations. They contained a relatively large amount of condensed heterochromatin and 1-2 peripherally located nucleolei. The nuclear membrane and its pores were distinct.

The cytoplasm of the basal cells had a greater electron density than that of other cells. The density was due chiefly to the large amount of ribosomes and tonofilaments which were arranged peripherally in a circumferential manner around the nucleus. It contained moderate amount of mitochondria which

Assiut Vet. Med. J. Vol. 32 No. 63, October 1994. 
appeared elongated, oval and round and few short cisternae of rough endoplasmic reticulum. The Golgi zone is vestigial if present at all.

\section{Intermediate cells:}

The intermediate cells (Fig. 3) were wedge-shaped, elongated and considerably more slender than the basal cells. They were located just above the basal cell layer with their longitudinal axis perpendicular to the epithelial surface. They were attached to their neighbors by few desmosomes and interdigitations through cytoplasmic processes as well as to the basal lamina by hemidesmosomes.

The nuclei were relatively large and oval with few indentations. In all other respects the intermediate cells were similar in both their cytoplasmic and nuclear componants to the basal cells but the cytoplasm was less electron dense due to the small amount of tonofilaments and ribosomes.

\section{Ciliated cells:}

The ciliated columnar cells (Fig. 4-7) were the most commen cell type in this epithelium extending from the basal lamina to the Luminal surface. These cillated cells were found to be of two types; a light and a dark one (Fig. 4).

The dark ciliated cells were more abundant cell type, while the light one were seen at variable intervals. These ciliated cells were joined to the adjacent columnar cells by tight junctions at their luminal surface. Laterally, they were joined together with few desmosomes and 111-developed cytoplasmic interdigitations which extended into a very narrow intercellular space as the lateral cell membranes were relatively straight. The intercellular space became wider basally. In addition, the ciliated cells contacted with the basal lamina by hemidesmosomes.

The ciliated cells were studded with numerous long cilia which were seen projected from the cell apex intermingled with short and branched microvilli (Fig. $6 \&$ \%). The nuclei were usually oval in the dark cells and round in the light one with somewhat irregular contour. Some clumps of heterochromatin as well as 1-2 small peripherally located nucleoli were seen. The nuclei of the light ciliated cells contained more euchromatin.

The cytoplasm of the dark ciliated cells was more electron dense than that of the light ones. This is due to numerous ribosomes, either dispersed in the cytoplasm or arranged in polysomes. The cytoplasm also contained variable shaped mitochondria which were distributed throughout the cell but more concentrated in the cell apex under the numerous basal bodies (Fig. 7). They were more numerous in the dark ciliated 
cells than the light ones. Short cisternae of rough endoplasmic reticulum were evenly distributed in both cell types. Large number of clear vesicles were regularly observed in most of the dark ciliated cells in the supranuclear region, which were fewer in the light ones (Fig. 4-6). Small bundles of tonofilaments as well as moderatly developed Golgi-elements were also seen (Fig. 5)

Goblet cells:

The goblet cells (Fig. $3 \& 8$ ) were constituted the mucous producing cell-type in the guttural pouch epithelium. They were often singly distributed and attached to the neighbours apically by tight junctions (Fig. 7); laterally with few desmosomes and interdigitations through short cytoplasmic processes. They become longer basally as the intercellular space became wide. At the basal border, they were contacted with the basal lamina by few hemidesmosomes.

The nuclei of the goblet cells were smaller than those of the ciliated ones and more basally situated. Most of their condensed heterochromatin was located adjacent to the nuclear envelope but some were scattered throughout the nucleoplasm. The nuclei had many pores in its limiting membrane and contained large dense nucleoli.

The cup-shaped apical portion of the goblet cells (Fig. 8 a) were frequently filled with secretory granules. The granules were variable in form and size as well as in staining density. They were mostly lightly stained. An electron dense core was noted in some granules.

The cytoplasm of the goblet cells was electron dense. It contained numerous cisternae of rough endoplasmic reticulum which were usually concentrated in the basal portion of the cell or occasionally located between the secretory granules. The elongated or rounded mitochondria were also scattered in the cytoplasm, in between the secretory granules or found parallel to the lateral cell membranes. A well developed supranuclearly located Golgi-apparatus as well as free ribosomes and tonofilaments were seen (Fig. 8 b).

According to the state of functional activities an exhausted as well as immature form of goblet cells were occasionally seen.

The exhausted goblet cells appeard more electron dense columnar shaped cells. Their apical surface were provided with microvilli. Few secretory granules were sometimes seen in the supranuclear region. Mitochandria and rough endoplasmic reticulum cisternae were scattered in the cell cytoplasm. The nucleus showed some indentation.

The immature cells (Fig. 3) appeared more slender formig. Their cytoplasm had the same electron density as that of the 
other ciliated cells. The secretory granules were located in the most apical region. Abundant mitochondria were scattered throughout the cytoplasm in addition to the other organelles.

\section{Migratory cells:}

In this investigation, variable number of intraepithelial lymphocytes (Fig. 2) and mast cells (Fig. 9) were observed at different levels of the epithelium. While the lymphocyte possessed an electron dense nucleus surrounded by moderate amount of cytoplasm, the mast cell cytoplasm was filled with electron leucent granules.

\section{DISCUSSION}

In this investigation, the ultrastructure of the surface epithelium of the guttural pouch of the donkey has been studied. It was found to be a typical pseudostratified columnar epithelium, consisted of four distinct cell types namely: basal, intermediate, ciliated and goblet cells similar to the respiratory epithelium lining human trachea (RHODIN, 1966), bronchi of the pig (BASKERVILLA, 1970a), nasal cavity of the mouse and man (MATULIONIS and PARKS, 1973; BUSUTTIL et al. , 1977 ) and larynx of the donkey (ABDEL-RAHMAN, 1990). However, it was characterized from the respiratory epithelium of other organs by numerous irregular invaginations of variable depths into which some goblet cells open. These characters of the mucous membrane of the guttural pouch are very considerable for its extensibility during inspiration and expiration as recorded by CHAUVEAU (1910).

The present work proved that the ultrastructure of the basal cells was nearly similar to that described by BASKERVILLA (1970a) in bronchial epithelium of the pig. BREEZE et al. (1976) in mammalian respiratory epithelium and $A B D E L-R A H M A N$ (1990) in the laryngeal epithelium of the donkey. In agree with CASORATI et al. (1965) the basal cells of the epithelium contained more filaments than the rest of the epithelial cells. They suggested that this feature is in keeping with the potential of these cells to undergo squamous change. On the contrary BRETTSCHNEIDER (1958); OKANO and SUGAWA (1965) and MATULIONIS and PARKS (1973) found that the basal cells of the nasal respiratory epithelium of the rat, canine and mouse respectively contained no filaments. RHODIN (1966) in human trachea and BLENKINSOPP (1967) in the rat respiratory epithelium stated that the basal cells mature into the more superficial epithelial and goblet cells.

The present study denoted that the intermediate cells were found above the basal cell layer and greatly resemble the basal

Assiut Vet. Med. J. Vol. 32 No. 63, October 1994. 


\section{YOUSRIA ABDEL-RAHMAN et al.}

cells in both their cytoplamic and the nuclear component as described by RHODIN and DALHMAN (1956); KONRADOVA (1966) and RHODIN (1966) in the tracheal epithelium of the rat, rabbit and human respectively, and by (BASKERVILLE, 1970a) in bronchial epithelium of pig. RHODIN (1966) in human tracheal epithelium stated that the regeneration of lost, sloughed ciliated and mucous- producing cells occurs through growth and differentiation of basal and intermediate cells. However, FRASCA et al. (1968) in the bronchial epithelium of dog mentioned that as the intermediate cell differentiates it becomes more electron dense as it strats to accumulate mucin granules or becomes more electron lucent with the onset of ciliogenesis.

As revealed from the present investigation the ciliated cells were found to be of two types, a light and a dark one due to an increased in electron density of its cytoplasm, this in accordance with that observation of OSADA (1963); HANSEL and MORETTI (1969) in human and mouse tracheal epithelium respectively and ABDEL-RAHMAN (1990) in dog and donkey laryngeal epithelium. While the light ciliated cells were the most abundant cell-type in the mouse tracheal epithelum (HANSELL and MORETTI, 1969) and the dog laryngeal epithelium ( $A B D E L-R A H M A N$, 1990), the dark ciliated cells were more numerous in the guttural pouch epithelium of donkey. From the morpho-physiological prespective, the present observation supports the suggestion of YAMADA (1968). that the light cells are an aged, degenerative cell-type with declining functional activity and a high degree of hydration. While the dark cells are characterized by a high concentration of mitochondria and free ribosomes, more or less distinctive elements of granular endoplasmic reticulum and well- developed Golgi apparatus. Such ultrastructural evidence indicates that the dark cell type has a high synthetic activity. The reported dark cells by BADER (1965 a \& b) in the gall bladder of $\mathrm{fish}$, frog and man were an intermediate cell-type in the course of the development and differentiation of ordinary epithelial cells from undifferentiated basal cells. This opinion appear to be highly unacceptable for the well-developed mature dark ciliated cells which were numerous in the guttural pouch epithelium of donkey.

The microvillous branching of ciliated cells, which increases the surface area of the apical border, was identical to that described in human nasal respiratory epithelium (BUSUTTIL et al., 1977) and dog respiratory epithelium (OKANO and SUGAWA, 1965). However, this feature was not reported in the ciliated cells of rat and mouse nasal mucosa (BRETTSCHNEIDER, 1958; MATULIONIS and PARKS, 1973).

The goblet cells in the donkey guttural pouch were similar to those in the respiratory epithelia of other species; rat 
trachea (RHODIN and DALHMAN, 1956), mouse nasal epithelium (MATULIONIS and PARKS, 1973), dog nasal epithelium (OKANO and SUGAWA, 1965), human nasal epithelium, (CASORATI et al., 1965; THAETE et al., 1981). They perform a protective functions for the body; assist in humidifying and cleansing the air, their secretion form a protective mucous coat covering the cilia. Results obtained in this work revealed that the secretory granules in the apical region of the goblet cell vary in size and in density, as described by FRASCA et al. (1968) the dog bronchus.

The present study reaveled that there were lymphocytes in normal guttural pouch epithelium. They may be immunologically competent cells (YOFFEY, 1962) or they may be involved in controlling growth as so called trophocytes (LOUTIT, 1962; $B U R C H, 1986)$. Although the exact functional significance of the distribution of mast cells in some epithelia is not yet clearly understood, the heparin as a lipid clearing factor (SHOULDERS and MENG, 1957) may be a possible explanation for scattering the mast cells in the guttural pouch epithelium, particurlarly the secretion of guttural pouch glands contains high amount of lipid (unpublished observation).

\section{REFERENCES}

Abdel-Rahman, A. Yousria (1990): Comparative macro- and micromorphological studies on the larynx of different domestic animals (Equidae, Rumenantia, Carnivora). Thesis, Ph. D. , Assiut-Giessen Univ.

Bader, G. (1965 a): Die submikroskopische Struktur des Gallenblasenepithels und seine Regeneration. 1- Mitt.: Karpfen (cyprinus carpio, L.) und Forsch (Rana esculenta, L. ). Z. Mikr. Anat. Forsch., 74: 92-107.

Bader, G. (1965 b): Die submikroskopische Strucktur des Gallenblasenepithels III. Mitt: Das Epithel der steingallenblase des Menschen. Frankfurt. Z. Path., 74: 502-511.

Banks, W.J. (1993): Applied veterinary histology. $3^{\text {rd }}$ Ed. Williams and Wilkins. Baltimore. London. Los Angeles. Sydney.

Baskerville, A. (1970 a): Ultrastructure of the bronchial epithelium of the pig. Zentralbl. Vet. Med., 17: 796-802.

Blenkinsopp, W.K. (1967): Proliferation of respiratory tract epithelium in the rat. Exp. Cell Res., 46: 144-154.

Boeck, P. (1984): Der Semiduennschnitt. J.F. Bergmann Verlag Muenchen.

Assiut Vet. Med. J. Vol. 32 No. 63, October 1994. 
Breeze, R.G.; Wheeld, E.B. and Pirie, H.M. (1976): Cell structure and function in the mammalian lung: The trachea, branchi and bronchioles. Vet. Bull., 46: 319-336.

Brettschneider, H. (1958): Elektronenmikroskopische Untersuchungen an der Nasenschleimhaut. Anat. Anz., 105: 194-204.

Burch, P.R.J. (1968): An inquiry concerning growth disease and ageing, p. 144. Edinburgh: Oliver and Boyd.

Busuttil, A.; More, I.A.R. and Mcseveney, D. (1977): A reappraisal of the ultrastructure of the human respiratory nasal mucosa. J. Anat., 124: 445-458.

Casorati, V.; Rosati Valente, R. and Silvagni, C. (1965): Ultrastruttura della porzione respiratoria della mucosa nasale umana. Annali dell' Istituto Superiore de Sanita, 1: 739-745.

Chauveau, A. (1910): The comparative anatomy of the domesticated animals. 2 nd Ed. New York and London. D. Apoleton and Co.

Cook, W.R. (1973): The auditory tube diverticulum (guttural pouch) in the horse: its radigraphic examination. J. Am. Vet. Rad. Soc. XIV(2): 51.

Dellmann, H.D. and Brown, E.M. (1987): Textbook of veterinary histology. $3^{\text {rd }}$ Ed. Lea and Febiger, Philadelphia.

Frasca, J.M.; Auerbach, O.; Parks, V.R. and Jamieson, J.D. (1968): Electron microscopic observations of the bronchial epithelium of dogs. 1- Control Dogs. Exp. Mol. Pathol., 9: 363-379.

Freeman, D.E. (1980 a,b): Diagnosis and treatment of diseases of the guttural pouch (Part I \& II). The compendium on continuing education. Lg. An (Suppl. I and II).

Hanse11, M.M. and Moretti, R.L. (1969): Ultrastructure of the mouse tracheal epithelium. J. Morph., 128: 159-170.

Haynes, P.F. (1984): Surgery of the equine respiratory tract: In the practice of large animal surgery by P. B. Jennings. W. B. Saunders Comp. Philadelphia.

Koenig, H.E. (1984): Topography of the guttural pouch in the horse. Zur Topographie des luftsackes (Diverticulum tubae auditivae) beim Pferd. Tieraerztliche Praxis, 2: 219-227.

Konradova, V. (1966): The ultrastructure of the tracheal epithelium in rabbit. Folia Morphol., 14: 210-214.

Liebich, H.G. (1990): Funktionelle Histologie. Farbatlas und Kurzlehrbuch der mikroskopischen Anatomie der Haussaeugetiere. Schattauer, Stuttgart- New York.

Loutit, J.F. (1962): Immunological and trophic functions of lymphocytes. Lancet, II: 1106-1108.

Matulionis, D.H. and Parks, H.F. (1973): Ultrastructural Morphology of the normal nasal respiratory epithelium of the mouse. Anat. Rec., 175: 65-84. 
Milne, D.W. and Fessler, J.F. (1972): Tympanitis of the guttural pouch in a foal. JAVMA, 161: 61-64.

Misk, N.A.; Ahmed, I.H. and Youssef, H.A. (1992): External fistulation for the treatment of guttural pouch tympany in two fillies. Equine pract.-surg., 1: 31-35.

Okanao, M. and Sugawa, Y. (1965): Ultrastructure of the respiratory mucous epithelium of the canine nasal cavity. Arch. Histol. Jap., 26: 1-21.

Osada, M. (1963): Electron Microscopical observations on the human tracheal epithelium, with special reference to the ciliated cells. Arch. Histol. Jap., 24: 91--111.

Rhodin, J. and Dalhman, T. (1956): Electron microscopy of the tracheal cillated mucosa in rat. Z. Zell forsch. Mikrosk. Anat. , 44: 345-412.

Rhodin, J. (1966): Utrastructure and function of the human tracheal mucosa. Amer. Rev. Resp. Dis., 93: 1-15.

Schummer, A. and Nickel, R. (1979): The viscera of the domestic mammals. 2- Ed. Verlag Paul Parey, Berlin and Hamburg.

Shoulders, H.H. and Meng, H.C. (1957): Effects of fat emulsion upon tissue mast cells. Federation Proceedings 16: 371.

Sisson, S. (1975): The ear. In Sisson and Grossman's: The anatomy of the domestic animals. Rev. by R. Getty, 5 - Ed. W. B. Saunders Comp., Philadelphia London. Toronto.

Thaete, L.G.; Spicer, S.S. and Spock, A. (1981): Histology, ultrastructure and carbohydrate cytochemistry of surface and glandular epithelium of human nasal mucosa. Am. J. Anat. 162: 243-263.

Yamada, K. (1968): Some observations on the fine structure of light and dark cells in the gall bladder epithelium of the mouse. Z. Zelforsch. Mikrosk- Anat., 84: 463-472.

Yoffey, J.M. (1962): The present status of the lymphocyte problem. Lancet, i: 206-211.

\section{LEGENDS}

Fig. 1: Semithin section of the gutturl pouch epthelium of donkey showing a pseudostratified ciliated columnar epithelium with goblet cells. Invaginations (arrowheads); mast cell (arrows); Lamina propria (Lp). Alcian blue-PAS. X 400 .

Fig. 2: Electron micrograph of the guttural pouch epithelium of the donkey demonstrates migrating lymphocytes occupying a basal position between two basal cells. Basal cell (BC), Lymphocyte (Lc). X 4000. 
Fig. 3: Electron micrograph of the respiratory epithelium of the guttural pouch. Basal cell (Bc); Ciliated cell (Cc); Goblet cell (Gc); Lumen (Lu); Basal lamina (Bl); Intercellular space (Is). X 2000.

Fig. 4: Electron micrograph shows dark and light ciliated cells containing vesicles (V) and mitochondria (arrowhead). X 4000.

Fig. 5: Higher magnifica tion showing secretory granules (Sg) in goblet cell and Golgi-apparatus (Ga); vesicles (V) and mitochondria (arrowheads) in the cilliated epithelial cells. X 20000.

Fig. 6: Higher magnification of the cilia and the apical portion of the ciliated cells demonstrates basal body (star) of the cilia; branched microvilli (Mv); vesicles (V) and tight junction ( $\mathrm{T} j \mathrm{j}) . \times 14000$.

Fig. 7: Electron micrograph of the apical portion of a ciliated cells showing cilia (thin arrow), branched microvilli (Mv), many of mitochondria (arrowheads), secretory granule $(\mathrm{Sg})$ in goblet cell and tight junction (Thick arrow). X 10000.

Fig. 8: Electron micrograph of the goblet cell.

a) General view.

b) Higher magnification of the supranuclear region. Lumen (Lu), Nucleus (N), Secretory granules $(\mathrm{Sg})$ with electron dense core (arrow), Golgi-apparatus (Ga), rough endoplasmic reticulum (FER), tonofilaments (Tf).
a: $\mathrm{X} 4000$
b: X 6700 .

Fig. 9: Electron micrograph shows intraepithelial mast cell. The cytoplasm was filled with electron lucent secretory granules (asterisk). X 6700 . 

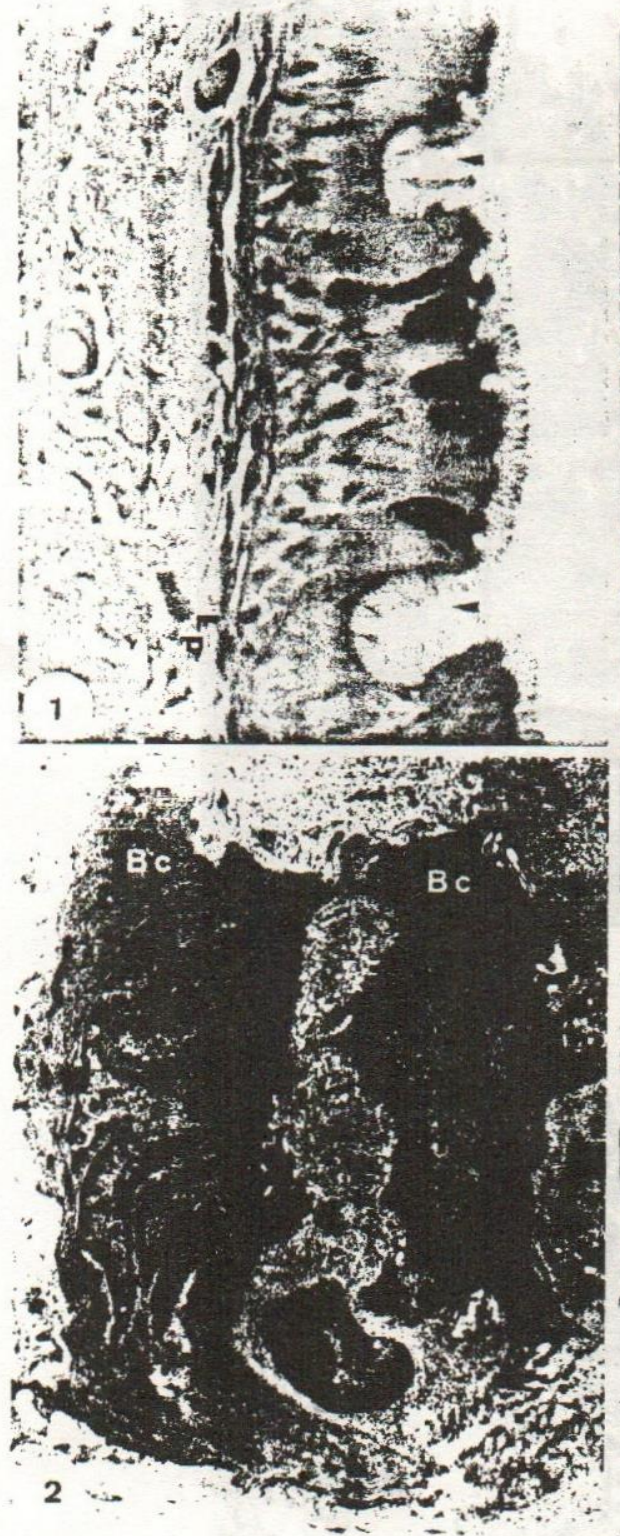

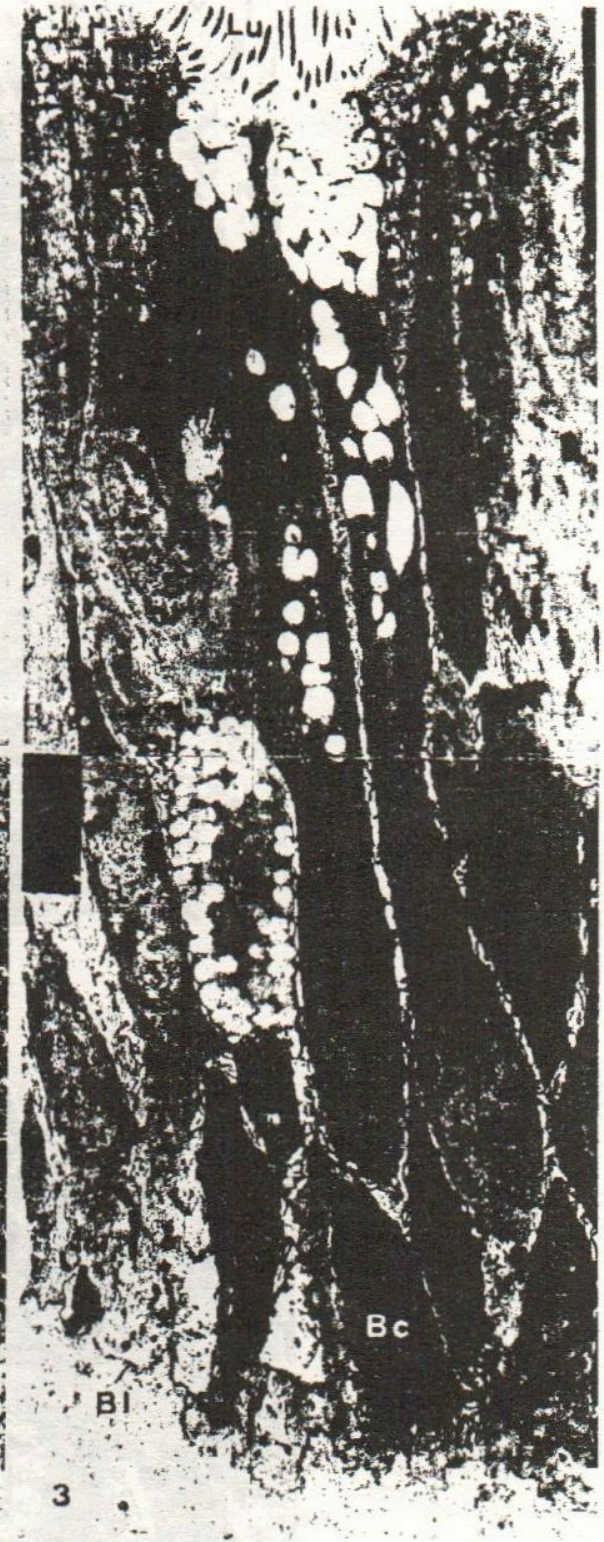




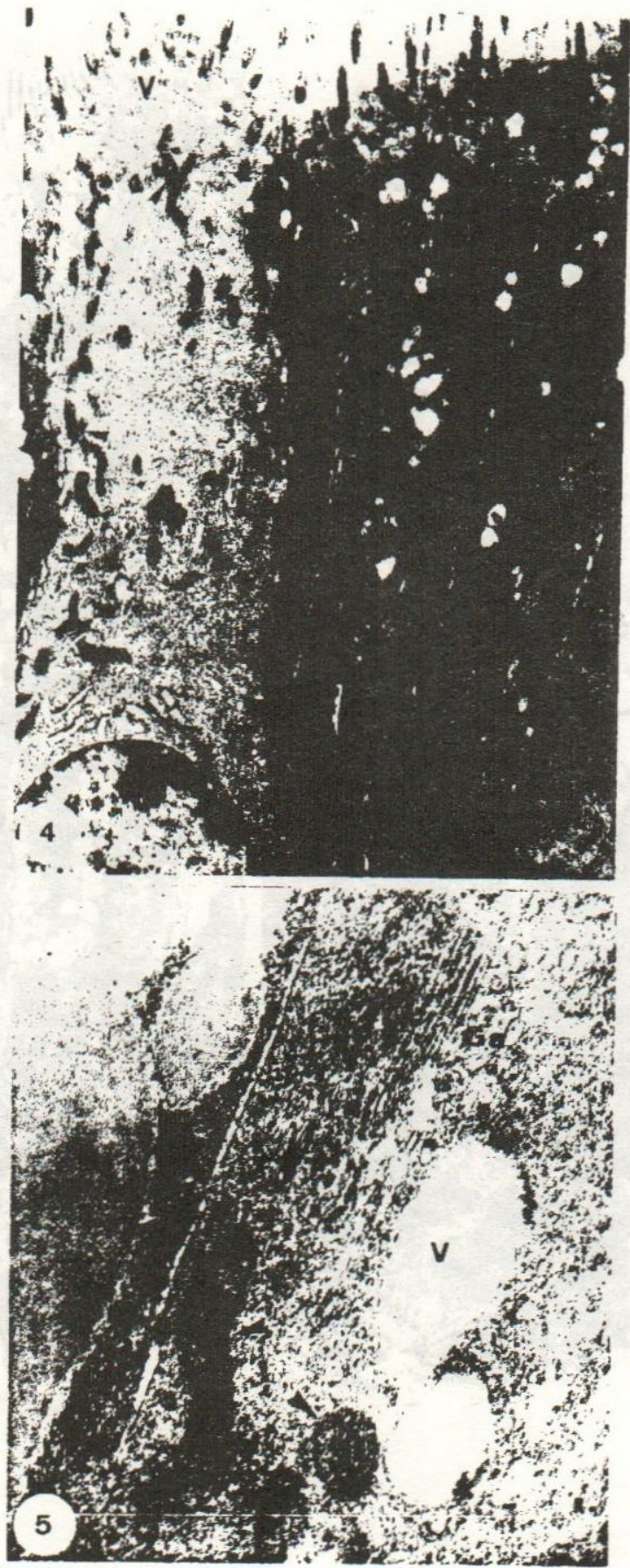




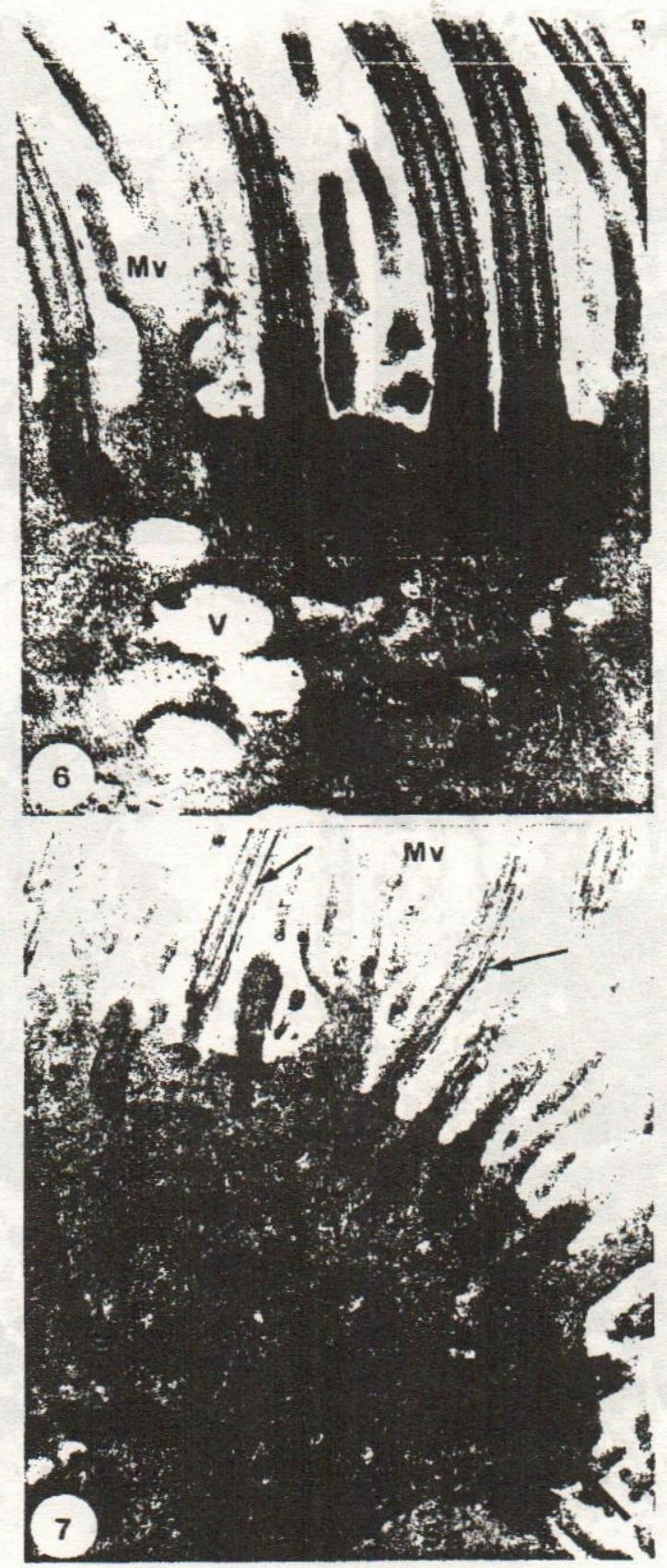




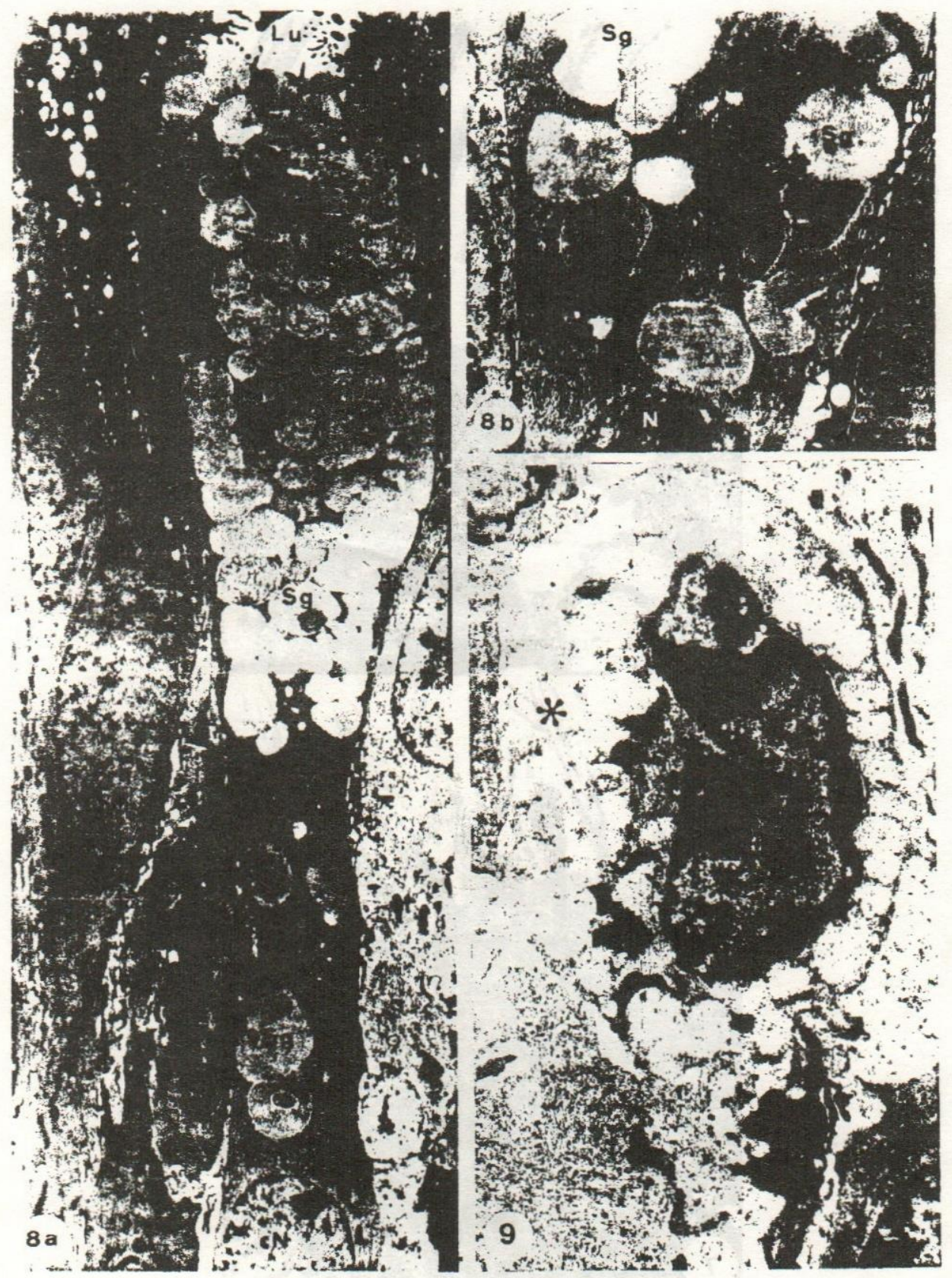

